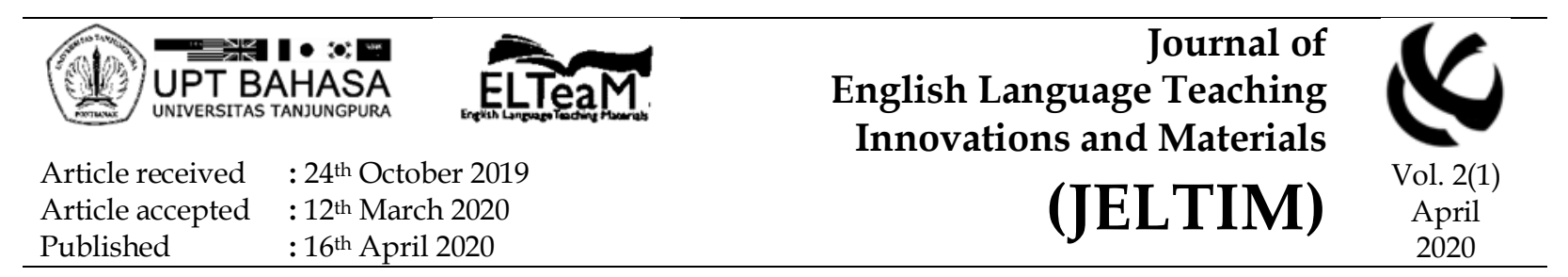

\title{
Extended reading: college students' attitudes In selecting reading materials
}

\author{
Novika Amalia \\ The Department of English, Faculty of Letters, Universitas Negeri Malang, \\ Jawa Timur, Indonesia \\ novika2311@gmail.com
}

DOI: http://dx.doi.org/10.26418/jeltim.v2i1.37231

\begin{abstract}
Appraising the trend that students are welcomed to independently make their own choices in learning, this study investigated college students' preferences and considerations on self-chosen materials for extended reading (ER). A survey was conducted on 32 college students majoring in ELT who has taken reading courses. The survey consisted of ten questions, all related to their preferences and considerations in choosing the materials to read for ER activities. The results extracted led to the conclusions that authentic materials are more favorable over graded readers, and the difficulty level of the text considered as the foremost priority. Interested researchers are apprised to conduct an experiment that allows better and deeper analysis to gain insights on providing materials for ER in the EFL contexts for the students to select by themselves.
\end{abstract}

Keywords: students' preference; EFL reading; reading material; extended reading

How to cite this paper: Amalia, N. (2020). Extended reading: college students' attitudes in selecting reading materials. Journal of English Language Teaching Innovations and Materials (JELTIM), 2(1), 25-35. DOI: http://dx.doi.org/10.26418/jeltim.v2i1.37231

Providing rich input in English is essential for promoting English proficiency. As a receptive skill, reading is vital in L2 academic settings where learners are required to read, learn and complete tasks related to reading (Anderson, 2015). Research to date has shown that reading abilities only gradually develop when L2 students are exposed to extensive and meaningful input or readings on a continuous basis.

Journal of English Language Teaching Innovations and Materials (JELTIM), 2(1), 25-35

Copyright ( 2020 by JELTIM, e-ISSN 2657-1617 
Extensive reading, or ER, is commonly defined as an activity in which learners read a lot of easy materials in a new language to read outside the classroom. ER can be called "pleasure reading," "free voluntary reading," and "sustained silent reading." ER is an excellent way to access target languages, particularly in foreign language environments, where the target language input is very limited. Such a way is also known for its ability to allow learners to understand the language through numerous reading for fun. To develop reading abilities in EFL settings, extensive reading has a better perspective as one of the most effective compared to the intensive reading approach. This is because extensive reading allows exposure to L2 learners in ample amount of meaningful input, as well as motivate L2 learners to read which leads to the development of skilled reading abilities (Jeon \& Day, 2016; Suk, 2016).

In the setting of ER, it should be of primary importance to provide information that students can appreciate without great frustration. To minimize such frustration, teachers supervising the activity often assist their students by mediating them with their reading materials and the author of the text. It is also a way of reducing the sum of reading materials to the linguistic ability of the learners. This leads to the question of whether authentic or simplified texts should be used. Authentic texts are, on the one hand, considered superior language learning devices but are potential pitfalls for learners not ready for them. On the other hand, while condensed texts can be best used by poor learners, they are not written properly and have a weakness, both in language and in substance. Studies regarding ER materials found that learners have their own preferences in choosing which materials they want to read, and such preference promotes their motivation in reading as well as their overall performance ER (Lin, Pandian, \& Jaganathan, 2016). Their preferences between graded readers and authentic materials vary depending on several factors such as their English proficiency and interest in the materials.

\section{Comprehension in Reading}

Two phases occur in reading: initial reading and reading comprehension. Initial reading occurs as readers learn letters, words and phrases at the very first stage. The purpose of reading comprehension, however, is to understand the text from the literal meaning of the sentences to the interpretative sense of the text as a whole. Grabe and Stoller (2011) emphasize that reading understanding is a complex set of skills that address speed, performance, communication, strategy, versatility, evaluation, guided, comprehension, learning and linguistic processes. Readers possessing and making use of these abilities will be able to reach a full understanding, which is the final goal of the reading activity itself.

Reading comprehension is not something that learners can acquire in a short time. Moreover, there is a danger of impeding understanding and

Journal of English Language Teaching Innovations and Materials (JELTIM), 2(1), 25-35

Copyright ( 2020 by JELTIM, e-ISSN 2657-1617 
demotivating learners by using texts that contain too many obscure and unfamiliar words, which renders them as unsuitable reading materials. For instance, for students with a relatively good knowledge of the English language, some texts may be understandable, and even if they would have some unfamiliar words, they would probably have enough established vocabulary to infer the importance of those words. In contrast, English language learners who are already struggling to cope with the language are unlikely to be able to comprehend much of the text.

\section{Motivation in Reading}

While motivation in reading tend to be associated with the readers considering it as something to get pleasure from, motivation actually occurs for various reasons. Ahmed (2016) spells out three reading motivations students may have: interest as they enjoy it, dedication as they believe it is important, and confidence as they can do it.

While these motivations seem positive, they do not necessarily apply to all students. Some students may find them to be demotivating instead, thus pulling themselves away from books. For example in the EFL context, teachers can incite students' confidence to read when the difficulty level is lower or matches students' comprehension level but can also cause the opposite when the difficulty level is higher instead. In reality, it is found that students who do not read are: learners who do not find the material to be interesting, those who believe its importance do not apply to them, and low achievers whose confidence declines overtime (Miyamoto, Pfost \& Artlet, 2018; Vaknin-Nusbaum et al., 2018). By selecting their own materials, it enhances the relatability of the reading content to the students' background and ability, thus contributing to their motivation. The current study will focus on students' motivations concerning interest, specifically their interest in graded readers and authentic materials.

\section{Materials for ER}

Lien (2010) investigated EFL College learners' perceptions of self-selection of extensive reading materials after five months of supplementary extensive reading for a college reading course. A total of 108 EFL freshmen majoring in English participated in the study for five months. The results indicate that $80 \%$ of the participants $(\mathrm{N}=108)$ indeed enjoyed ER. Participants that did not like to read in English generally tend to select classified readers. More individuals seemed more willing to engage in reading authentic books. For EFL college learners at the high intermediate level, graded readers did not seem to be enough. The instructor implementing ER may need to provide various graded readers and authentic materials suitable for their levels and needs.

Journal of English Language Teaching Innovations and Materials (JELTIM), 2(1), 25-35

Copyright ( 2020 by JELTIM, e-ISSN 2657-1617 
Throughout Lin et al's (2016) study, the authentic and simplified texts in the ESL/EFL settings are discussed, and the students ' assumptions about using graduate readers are tracked. In a Malaysian undergraduate program, 28 remedial English learners were given a series of graded readers, which then were given a questionnaire to track their preferences. The main findings were that: 1) perception toward graded readers were encouraging, and 2) suitable materials can be beneficial, especially to develop positive attitude on English reading.

Drawing on the findings of these studies, learners have their own preferences in choosing which materials they want to read for ER, and such preference promotes their motivation in reading as well as their overall performance.

\section{Graded Readers}

Graded readers or "Language learner literature" are simplified texts specially written for L2 learners at various levels of language proficiency (Day \& Bamford, 1998) and carefully divided into reading proficiency levels to improve language learners' reading competency (Waring, 2005). Graded readers are able to provide a sense of confidence and security for L2 learners to read in a foreign language by restricting the word count and simplifying grammar structures. This type of material is commonly either the revamped or the condensed version of the original material.

Graduate readers are widely recognized as a means of improving reading skills by helping students gain enough fluency at one level to progress to the next level. More and more studies have also demonstrated the need and benefit of the full use of graded readers, claiming that simplified language text is as relevant and useful as real language learning material. Authentic reading and listening, on the other hand, are usually more difficult. The increasingly understandable input, making L2 literature accessible and fun, enabling learners to assume responsibility for their own language education, embracing almost all grades of learners and building better English reading habits, are the benefits of integrating graded readers into the language classroom.

\section{Authentic Materials}

The term authentic materials have been defined differently. This paper applies the definition by Bacon and Finnemann (1990), stating that authentic materials are texts created by native speakers for non-pedagogical purposes. This definition is because it specifies the producers of the text as native speakers, a detail which usually are not mentioned.

Although they are primarily defined as materials written for native speakers, not for language learners, authentic texts are important for language

Journal of English Language Teaching Innovations and Materials (JELTIM), 2(1), 25-35

Copyright ( 2020 by JELTIM, e-ISSN 2657-1617 
learning, for the benefits of increasing students' motivation for learning and giving them exposure to the 'real' language. Research studies have investigated the benefits of using authentic materials in language classrooms, indicating that giving a positive impact on learner engagement, offering accurate cultural information and access to specific languages, approaching apprenticeship needs more closely, and promoting a more creative approach to learning are the key benefits of using authentic resources.

\section{The Present Study}

The present study acknowledges three factors that students may consider when selecting the materials to read for ER: interest, knowledge, and difficulty. These three factors are adopted for there are studies revealing that topic interest, background knowledge, and difficulty level (in consideration of student's language proficiency), have moderate to significant effects on learners' reading performance and comprehension scores. (Lee \& Pulido, 2016; Bahmani \& Farvadin, 2017)

This study essentially has the purpose of eliciting college students' preferences on self-chosen materials for ER, and their considerations in choosing which materials for them to read. This study focuses only on materials of ER. Research questions are formulated as follows:

1) Do the college students favour graded readers or authentic materials for ER?

2) What are the college students' considerations in selecting materials to read?

\section{METHOD}

\section{Participants}

The population is undergraduate students of a state university in Banjarmasin majoring in ELT. The 32 respondents taking part in the study were active college students who have experience or currently taking a reading course at college level.

\section{Study Design}

The population is undergraduate students of a state university in Banjarmasin majoring in ELT. The 32 respondents taking part in the study were active college students who have experience or currently taking a reading course in college level. 


\section{Instruments}

A questionnaire, which is spread among the population, consisted of 10 questions with additional 2 initial questions to identify the participants, all with predetermined responses. The first question asked whether the participants are an active college student in a university in Banjarmasin, and the second one asked whether they have taken or were taking a Reading course. The questionnaire itself was all regarding their behaviour in ER and their preferences for the material (authentic materials and graded readers) and their considerations in choosing their ER materials (interest, knowledge, and text difficulty).

\section{Procedures}

The questionnaire was distributed among the population through online means. As the potential participants clicked the link provided, they will be directed to a webpage where they were asked to answer the survey consisting of 10 questions with a predetermined response. The data was then extracted from their responses, analyzed in order to investigate their preferences and considerations regarding the materials for ER.

\section{FINDINGS}

As has been stated earlier in the article, this study has the main purpose of eliciting college students' preferences on self-chosen materials for ER, and their considerations in choosing the materials. There were a total of 32 respondents participated in this study. The findings of the study are presented based on the research questions (RQ).

\section{RQ1: Do the college students favour graded readers or authentic materials for ER?}

This RQ is addressed to the respondents through three questionnaire items. All three are made to extract the information on respondents' preferences between authentic materials and graded readers. The responses collected through relevant questionnaire items are presented in Table 1.

Table 1. Responses on Preferences between Authentic Materials and Graded Readers.

\begin{tabular}{clcl}
\hline No & \multicolumn{1}{c}{ Questionnaire item(s) } & Yes & No \\
\hline 1 & Do you find authentic materials helpful for extensive reading? & $100 \%$ & $0 \%$ \\
2 & Do you find graded readers helpful for extensive reading? & $100 \%$ & $0 \%$ \\
3 & $\begin{array}{l}\text { Do you prefer authentic materials than graded readers for } \\
\text { extensive reading? }\end{array}$ & $79 \%$ & $21 \%$ \\
\hline
\end{tabular}

In question one, respondents are asked whether they consider authentic materials to be of help in ER. In question two, they are asked whether they consider graded readers to be helpful in ER. In question three, they are asked

Journal of English Language Teaching Innovations and Materials (JELTIM), 2(1), 25-35

Copyright ( 2020 by JELTIM, e-ISSN 2657-1617 
which reading material they perceive to be more helpful. By answering yes, they meant to favour authentic materials, while answering no means that they favour graded readers. The result showed that respondents wholly agreed $(100 \%)$ that both authentic materials and graded readers are helpful for extended reading. As for preferences, more than half $(79 \%)$ of respondents prefer authentic materials for extended reading activities than graded readers $(21 \%)$.

\section{RQ2: What are the college students' considerations in selecting materials to read?}

The second RQ is addressed through seven questionnaire items. Six are made to extract the information on respondents' considerations in selecting ER materials. The responses collected through relevant questionnaire items are presented in Table 2.

Table 2 Responses on Considerations when Selecting ER Materials to Read.

\begin{tabular}{clcc}
\hline No & \multicolumn{1}{c}{ Questionnaire item(s) } & Yes & No \\
\hline 4 & $\begin{array}{l}\text { Is your interest in the topic of the text important when choosing } \\
\text { which to read? }\end{array}$ & $100 \%$ & $0 \%$ \\
5 & $\begin{array}{l}\text { Is your background knowledge in the topic of the text important } \\
\text { when choosing which to read? }\end{array}$ & $64 \%$ & $36 \%$ \\
6 & $\begin{array}{l}\text { Is the difficulty level of the text important when choosing which } \\
\text { to read? }\end{array}$ & $100 \%$ & $0 \%$ \\
7 & $\begin{array}{l}\text { Is a text with interesting topic helpful for extensive reading? } \\
8\end{array}$ & $\begin{array}{l}\text { Is a text with a topic you understand helpful for extensive } \\
\text { reading? }\end{array}$ & $46 \%$ \\
9 & $\begin{array}{l}\text { Is a text with preferable difficulty level helpful for extensive } \\
\text { reading? }\end{array}$ & $100 \%$ & $0 \%$ \\
\hline
\end{tabular}

The findings show that respondents considered all three factors, namely their interest, their knowledge, and the text's difficulty to be relatively important and helpful to some extent. It was found that in selecting reading materials, respondents were taking into account of their interest in the topic (100\%), background knowledge (64\%), and the difficulty level of the text $(100 \%)$. As for helpfulness, respondents mostly attribute it to the difficulty level of text $(100 \%)$, their comprehension on the topic (79\%), and their interest in the topic (54\%).

The last questionnaire item was constructed to conclude the previous six items, to figure out which of the three factors that the participants consider to have the highest priority when choosing a material that they have to read until the end. The responses collected on this questionnaire item are presented in Table 3.

Journal of English Language Teaching Innovations and Materials (JELTIM), 2(1), 25-35

Copyright ( 2020 by JELTIM, e-ISSN 2657-1617 
Table 3 Responses on student's preferences when selecting ER materials to read.

\begin{tabular}{llccc}
\hline No & \multicolumn{1}{c}{ Questionnaire item(s) } & $\begin{array}{c}\text { Intere } \\
\text { st }\end{array}$ & $\begin{array}{c}\text { Know } \\
\text { ledge }\end{array}$ & $\begin{array}{c}\text { Text } \\
\text { diffic } \\
\text { ulty }\end{array}$ \\
\hline 10 & $\begin{array}{l}\text { When you are choosing a material that you must } \\
\text { read until the end, do you prioritize your interest, } \\
\text { your knowledge, or the difficulty level of the text? }\end{array}$ & $21 \%$ & $25 \%$ & $54 \%$ \\
& & \\
\hline
\end{tabular}

It was discovered through this questionnaire item that their top priority when choosing materials for ER is the difficulty level of the text (54\%), followed by their background knowledge (25\%) and interest $(21 \%)$ in the topic of the reading materials.

\section{DISCUSSION [BOOK ANTIQUA 12 CAPITAL BOLD]}

Based on the findings, all respondents demonstrated a positive attitude towards both authentic materials and graded readers, considering both to be helpful for ER activities. Yet when asked on their preferences between the two, the findings showed that most of the respondents (79\%) favoured authentic materials as more useful reading material. These findings support the theories claiming that authentic materials have positive effects on student's motivation in reading, and additionally such materials have the advantages of providing a real exposure of the language itself (Guariento \& Morley, 2001; Richard, 2001). All respondents also agreed that their interest in the topic is important, but only a little more than half (54\%) stated that their interest is actually helpful in ER. Regarding background knowledge, $64 \%$ of the respondents consented that it is a major consideration when choosing what to read, and $79 \%$ of them found it to be truly accommodating for reading. As for the difficulty level of the text, all of the respondents were in accord that it holds great value when choosing reading materials and a significant aid in completing their ER tasks. It was discovered that their top priority when choosing materials for ER is the difficulty level of the text (54\%), followed by their background knowledge (25\%) and interest $(21 \%)$ in the topic of the reading materials.

Relating the findings with each other, a certain discrepancy was found in the responses provided by the respondents, which is most visible regarding their interest in the reading texts. While the respondents wholly agreed that their interest is important, only a little more than half (54\%) affirmed its usefulness, and only less than a quarter $(21 \%)$ of the respondents put it at the top of their priority when selecting their ER materials. On the other hand, the responses regarding their perception of their background knowledge seem to be more consistent. More than half $(64 \%)$ of the participants perceived it to be important, and more than three fourth $(79 \%)$ found it useful, then a quarter $(25 \%)$ of them made it their priority in choosing which material to read. Ultimately, the survey

Journal of English Language Teaching Innovations and Materials (JELTIM), 2(1), 25-35

Copyright ( 2020 by JELTIM, e-ISSN 2657-1617 
discovered that the difficulty level of the text is the most important and the most useful factor in ER, becoming the top priority in selecting ER materials as has been asserted by $54 \%$ of the respondents.

The factor of interest may often be viewed to be the ideal one for reading activities. However, other factors, such as their background knowledge and the difficulty level of the text interfered in the process. Thus, in reality, students disregarded their interest if the material contains the information they did not previously know or if it is written in a language that is difficult to understand. With these findings in mind, the study concludes that the factor of the text's difficulty level is the one that college students considers the most for their reading. This finding supports the statements asserting that reading materials should fall within the students' linguistic competence and that students' preferences promote their motivation in reading as well as their overall performance (Lien, 2010; Lin et al., 2016). Truly, the students in this setting seem to be prioritizing their own capability in completing the ER tasks, thus subsequently instigating them to choose materials that are deemed to be proportionate to their English proficiency. In order to avoid the risk of failing the task, these students disregarded their interest and background knowledge and prioritizing the text's difficulty instead.

\section{CONCLUSION}

The study's principal purpose was to find out college students' preferences on self-chosen materials for ER and their considerations in choosing the materials. All in all, the findings of the study lead to the statement that college students, in the current context, has the tendency to favour authentic materials over graded readers and to consider the difficulty level of the text as the top priority for self-selected ER materials. Practitioners who employ ER in their EFL classes are advised to mind the difficulty level of the materials and the students' proficiency level when providing them with reading texts. Alternatively, giving students the freedom to choose their own ER materials among a certain set of selection is also preferable.

There are a number of limitations to keep in mind before giving careful consideration of the findings of the study. First, the questionnaire used in the survey were items with simple closed responses, with items Q1-Q9 as a yes/no responses and item Q10 as a multiple-choice item. The nature of the questionnaire itself had limited the possibility to extract more in-depth data. Second, the responses collected in the study has a certain tendency to be positive, which is probably because of them learning English in college-level, thus having adequate fluency to read most of the materials for ER. This is most visible in the responses questionnaire item 1 and 2, in which a hundred per cent of the participants claimed to perceive both authentic materials and graded readers to

Journal of English Language Teaching Innovations and Materials (JELTIM), 2(1), 25-35

Copyright ( 2020 by JELTIM, e-ISSN 2657-1617 
be helpful for ER. Third, there was a time constraint on the researcher's part wherein there was a time limit in collecting data, thus limiting the number of respondents to reach. This also means that the findings exclusively applies to the context and setting in which the respondents' were.

Keeping the limitations of the study in mind, conducting a similar study in a different or wider context with an instrument that allows better and deeper analysis is advised for interested researchers. Such research will allow insights relevant to providing materials for ER in the EFL contexts, both for the ones the teacher selected for students, or for setting a selection for students to choose on their own.

\section{REFERENCES}

Ahmed, Z. A. D. 2016. The effect of motivation on developing EFL learners' reading comprehension skills. International Journal of English Language Teaching, 4(10), 1-9.

Bacon, S. M., \& Finneman, M. D. (1990). A study of the attitudes, motives, and strategies of university foreign language students and their disposition to authentic oral and written input. The Modern Language Journal, 74(4), 459473. http:/ / dx.doi.org/10.1111/j.1540-4781.1990.tb05338.x

Bahmani, R. \& Farvardin, M. T. 2017. Effects of different text difficulty levels on EFL learners' foreign language reading anxiety and reading comprehension. Reading in a Foreign Language, 29(2), 185-202.

Bamford, J., \& Day, R.R. (2004). Extensive reading activities for teaching language. New York: Cambridge University Press.

Cresswell, J. W. (2012). Educational Research: planning, conducting, and evaluating quantitative and qualitative research, 4th edition. Pearson Education, Inc.

Day, R.R., \& Bamford, J. (1998). Extensive reading in the second language classroom. New York: Cambridge University Press.

Grabe, W., \& Stoller, F.L. (2011). Teaching and researching reading (2nd ed.). New York, NY: Routledge.

Guariento, W., \& Morley, J. (2001). Text and task authenticity in the EFL classroom. ELT Journal, 55(4), 347-353.

Jeon, E. \& Day, R. R. (2016). The effectiveness of ER on reading proficiency: A meta-analysis. Reading in a Foreign Language, 28(2), 246-265.

Journal of English Language Teaching Innovations and Materials (JELTIM), 2(1), 25-35

Copyright ( 2020 by JELTIM, e-ISSN 2657-1617 
Lee, S. \& Pulido, D. (2016). The impact of topic interest, L2 proficiency, and gender on EFL incidental vocabulary acquisition through reading. Language Teaching Research, 21(1), 118-135. https://doi.org/10.1177/ 1362168816637381

Lien, H. (2010). EFL college learners' perceptions of self-selected materials for Extensive reading. The English Teacher, 39, 194-204.

Lin, D. T. A., Pandian, A., \& Jaganathan, P. (2016) Encouraging ESL/EFL Reading Among Lower Proficiency Students at the Tertiary Level: The Use of Graded Readers. The Reading Matrix: An International Online Journal, 16(2), 20-36.

Miyamoto, A., Pfost, M., \& Artelt, C. (2018). Reciprocal relations between intrinsic reading motivation and reading competence: A comparison between native and immigrant students in Germany. Journal of Research in Reading, 41(1), 176-196. https:/ / doi.org/10.1111/1467-9817.12113

Richards, J. C. (2001). Curriculum development in language teaching. Cambridge: Cambridge University Press. http://dx.doi.org/10.1017/ CBO9780511667220

Suk, N. (2016). The Effects of Extensive Reading on Reading Comprehension, Reading Rate, and Vocabulary Acquisition. Reading research quarterly, 52(1), 73-89. http://doi.org/10.1002/rrq.152

Vaknin-Nusbaum, V., Nevo, E., Brande, S., Gambrell, L. (2018). Developmental aspects of reading motivation and reading achievement among second grade low achievers and typical readers. Journal of Research in Reading, 41(3), 438-454. https:/ / doi.org/10.1111/1467-9817.12117

Waring, R. (2005). Graded and extensive reading: questions and answers. The Language Teacher Online, 21(5), 1-6.

\section{Authors' Brief CV}

Novika Amalia is a graduate student of the English Department, Faculty of Letters, the State University of Malang and will be graduating with a Master Degree in ELT. Amalia has a strong interest in the field of psychology in education and pedagogical practices in the classroom. 